\title{
Estar no lugar de alguém: um processo de negociação entre espectador e personagem a partir da "experiencialidade"
}

\section{Being in the place of someone: a process of negotiation between spectator and character from "experientiality"}

Regiane Regina Ribeiro ${ }^{1}$ e Valquíria Michela John²

1 Doutora e mestra em Comunicação e Semiótica (PUC-SP). Docente do Programa de Pós-Graduação em Comunicação da Universidade Federal do Paraná e dos cursos de graduação do Decom/UFPR. Líder do Grupo de Pesquisa NEFICS Núcleo de Estudos em Ficção Seriada (PPGCOM/UFPR). E-mail: regianeribeiro5@gmail.com. 


\section{Resumo}

$O$ artigo em questão discute o processo de produção de sentido em que se desloca a atenção para os personagens na ficção seriada. $O$ argumento defendido é de que as séries tendem a elaborar um jogo para o receptor que, mesmo imerso em um enredo, é supervalorizado. Assim, o que se pretende apresentar como hipótese é que, na narrativa das séries, a centralidade do enredo é enfraquecida em função do processo de negociação pela audiência que, a partir da "experiencialidade", coloca-se no jogo de repetir a trajetória de alguém. Tais argumentações pretendem responder a seguinte questão: o consumo das séries é uma tentativa de experiência estética relacionada mais a um convite de vivenciar no presente o lugar do personagem do que o de ser conduzido pela narrativa na qual já se prevê os acontecimentos? Parte-se de uma discussão teórica sobre o crescimento do consumo de ficção seriada, a estrutura desse texto narrativo e a relação entre esse tipo de consumo e a experiência estética, ou seja, um modo específico de temporalidade e de fruição, nas quais o receptor está implicado.

Palavras-chave

Consumo midiático, ficção seriada, "experiencialidade", experiência estética, personagem.

\section{Abstract}

The article discusses the relationship between character and narrative in serial fiction. The argument is that, in the series, a game for the reader/ spectator is formulated, weakening the notion of end, and at the same time strengthening the notion of character. Thus, what is hypothesized is that in the narrative of the series the centrality of the plot is weakened due to the negotiation process of the audience, that from the "experientiality" puts itself in the game of repeating someone's path. Such arguments are intended to answer the following question: is the consumption of series an attempt of aesthetic experiment much more related to an invitation to experience the place of the character in the present than to be guided by the narrative in which events are already foreseen? The starting point is a theoretical discussion about the growth of serial fiction consumption, the structure of the narrative text and the relation between this type of consumption and the aesthetic experience - in other words, a specific mode of temporality and enjoyment in which the receiver is involved.

\section{Keywords}

Media consumption, serial fiction, "experientiality", aesthetic experience, character. 
"Uma vivência, algo pelo qual simplesmente eu passei, eu atravessei, ou algo que me aconteceu, ela não é nada se não puder ser transformada em alguma narrativa compartilhável e transmissivel ao grupo ao qual eu pertenço. É a transmissão, é o compartilhar, que transforma a vivência em experiência." (Walter Benjamin)

No início de sua obra Do que as séries americanas são sintoma?, François Jost lança algumas perguntas que são retomadas no início deste artigo: de onde vem a paixão pelas séries? O que sustenta, atualmente, essa relação do espectador com a ficção seriada? Por que as séries gozam de tanta popularidade? No decorrer do texto, Jost reafirma que é ilusório imaginar uma única resposta, mas sim possibilidades. Bernardo Barros Oliveira (2015), filósofo brasileiro, apresenta as mesmas inquietações e desenvolve um argumento no qual esse fascínio pelas séries está associado a um tipo de fruição ou experiência estética que remodela a nossa percepção. Balizando ambas as afirmações, esse artigo pretende, numa perspectiva teórica, problematizar aspectos que envolvem os sujeitos consumidores dessas narrativas e a adesão tão significativa a esses conteúdos.

Entendendo as séries enquanto formato (BALOGH, 2002; MUNGIOLI, 2012), processo de categorização que não se encontra no interior dos textos, mas que opera por meio de práticas culturais que envolvem mercado, audiência, contexto histórico, crítica especializada (FISKE, 1987; MARTÍN-BARBERO, 2001; FEUER, 1992; MITTEL, 2004) "pode-se aferir que o seu sucesso deve-se menos aos procedimentos que ela utiliza (visuais, retóricos, narrativos etc.) do que ao ganho simbólico que ela possibilita ao espectador" (JOST, 2012, p. 25). Jost atribui esse ganho a estratégias bastante utilizadas pelo formato: a primeira está ligada à ideia de "atualidade" dividida em duas faces, a "dispersão" (credibilidade ficcional ocorrida pela aparição e ausência de acontecimentos) e a "persistência" (acontecimentos que se repetem e são sempre recordados na trama). A segunda estratégia é chamada pelo autor de "universidade antropológica", o termo se refere à exploração do que há de humano no espectador e amplia os modelos dicotômicos de leitura das narrativas. A terceira estratégia discute o papel da imagem enquanto processo de midiatização e pode ser sintetizada na seguinte afirmação: "No mundo das séries, a verdade 
surge sempre através das imagens: imagens da atualidade que a TV despeja, ou imagens índices que confundem [...]" (JOST, 2012, p. 32).

O papel da narrativa e do roteiro obviamente são fundamentais, se analisarmos o gatilho para esse hábito de consumo. Uma característica importante desse formato ficcional está em sua estrutura em que o fim de um episódio remete ao próximo, convocando o espectador a continuar, como se cada fim fosse provisório e um novo começo pudesse se iniciado com um simples clique. Sobre a noção de fim, Bernardo Barros Oliveira (2015) afirma:

Acompanhar uma narrativa, seguir uma história é, então, ser convidado a fazer uma experiência, a de se colocar neste entre um início e um fim. Quem segue uma história o faz sabendo a todo momento que um fim já está presente em simultaneidade a todas as ações sucessivas, e que todos os acasos, encontros e desencontros que é levado a testemunhar convergem neste fim, em relação ao qual ele vai tecendo hipóteses provisórias, até o momento em que sua hipótese coincidirá com aquilo que ele lê, vê ou ouve (OLIVEIRA, 2015, p. 17).

Esse potencial de imersão do receptor tem forte relação com as formas de distribuição. Inseridas no processo da chamada convergência midiática, muitas séries são produzidas para a TV, mas levando em conta toda uma legião de fãs que consomem suas histórias a partir da prática dos downloads e da rede de compartilhamento informal que se forma pela internet, além do crescimento da oferta das plataformas de streaming. Esses conteúdos não são apenas compartilhados, mas também, discutidos, contestados, elogiados, ressignificados e reelaborados em outros conteúdos, narrativas e suportes, seja em redes sociais, blogs, fanfictions, memes, sites ou fóruns dedicados aos temas das séries. Segundo Silva (2010), o espectador

[...] pode assistir todos os episódios de maneira sequencial sem ter que esperar pelo próximo numa semana futura (como ocorre nas produções televisivas de canais fechados e abertos). Mais do que isso: ele pode rever e assistir onde e quando quiser, além de tomar conhecimento de uma série inteira que possui três temporadas, por exemplo, em poucos dias ou horas (dependendo de sua vontade unicamente) (SILVA, 2015, p. 6). 
Esse modelo de consumo, chamado de binge watching, refere-se a uma sequência de assistência ininterrupta de um seriado. Conforme Silva (2015) "ele pode ser visto como um novo hábito, comportamento ou tendência no consumo midiático" (p. 7). Ainda segundo o autor, o binge watching não faz menção às maratonas de séries, mas ao consumo de algo inédito, fora do conceito de exibição tradicional, além do fenômeno da reassistência que reforça a "fidelização". Barros Oliveira também discorre sobre esse fenômeno e o relaciona com o potencial de fruição:

[...] as séries, se as olhamos isoladamente, desconectadas dos hábitos que regem nossa percepção cotidiana, são formalmente muito semelhantes aos folhetins, e mais ainda, aos seriados de TV. Mas o hábito de assistir capítulos on-line em sequência de modo compulsivo, não. Existiria uma remodelagem da nossa percepção intermediando este vício (BARROS OLIVEIRA, 2015 p. 211).

Martín-Barbero (1999) já defendia essa ideia de remodelagem perceptiva em seu mapa noturno. Para ele a recepção dos conteúdos midiáticos está fortemente atrelada à experiencialidade (sensorium), o que ficou conhecido como pós-modernismo audiovisual. Novos modos de ver marcado pelas experiências de nomadismo, instantaneidade e fluxo, isto é, por uma presença que se ramifica em manifestações diversas e efêmeras. Sobre essa potencialidade sensorial, García Rivera afirma:

Um sistema sinestésico como o já constituído por muitos filmes, videogames ou ficções organizados em diferentes linguagens requer respostas rítmicas de acordo com diferentes níveis: temos uma sensação física, uma reação motora e, finalmente, um significado psíquico. Toda essa gama de sensações é o que um fã experimenta quando se apropria de sua saga favorita: uma corrente de admiração que leva ao entusiasmo e a todas as suas manifestações externas, como as fantasias ou cosplay, e finalmente uma apropriação do sentido que o leva criar e compartilhar com os outros uma identidade ou afinidade através desse universo de ficção comum" (GARCÍA RIVERA, 2014, tradução nossa) ${ }^{3}$. 
A fruição por meio de um novo fluxo, nas séries on-line, está atrelada ainda à estrutura narrativa, na qual o fim de um episódio não pode bastar por si mesmo, ele deve prometer um novo começo e renovar a cada episódio o prazer e o interesse do espectador. Nesse processo, remodelar e ressignificar dizem respeito a um novo tipo de relação com a narrativa, uma imersão no espaço ficcional, uma experiencialidade possibilitada por uma nova temporalidade e tecnicidade. A questão central do artigo é discutir de que forma essa nova temporalidade determina um tipo de experiência estética em que o espectador potencializa sua relação com os personagens e vivencia seu lugar na trama? Essa experiencialidade pode vir a ser um dos possíveis comportamentos a indicar que o receptor demonstra um modo específico de temporalidade e fruição? No que ele difere do consumo de romances ou de ficção seriada tradicional ou telenovela?

\section{Experiência e o tempo narrado}

A experiência, em uma perspectiva filosófica, pode ser compreendida como o conhecimento transmitido pelos sentidos, ou seja, a apreensão sensível da realidade externa. Refere-se, portanto, a um processo de correlação entre o nosso eu biológico (percepção pelos sentidos) e nosso eu sociocultural (a sensibilidade que resulta desse processo). Embora esses aspectos estejam mais relacionados a perspectivas que vêm da psicologia e essa estabeleça seu foco de interesse na ótica do sujeito individual, essas premissas já apontam para a indissociabilidade entre o individual e o coletivo. Como então pensar a experiência como uma mediação central na compreensão não apenas das relações que os sujeitos estabelecem com as narrativas midiáticas, mas, sobretudo com o modo como se relacionam no e com o mundo onde vivem?

A temporalidade da recepção, imersa em novo sensorium e tomada como aspecto revelador das contradições da vida moderna, despertou a atenção de Benjamin. Para ele, a infância e os objetos culturais que fazem parte desse universo são interessantes por serem fenômenos marginais, que permitem conhecer a vida cotidiana e suas transformações, 
Mais do que estar interessado nos grandes momentos da história, dos grandes homens, das batalhas, dão lugar ao cotidiano da cidade, e ao que ele chama de história secreta da cidade, a anedota. Preocupa-se com os anúncios, as vitrines, os cartazes, todos os tipos de objetos efêmeros, cartas, diários pessoais, qualquer tipo de fenômeno marginal. $E$ é isso que the permite conhecer a verdadeira vida cotidiana do século XIX. Benjamin se considerava uma espécie de sucata e coletor de lixo (WECHSLER, 2015, tradução nossa) ${ }^{4}$.

Para Benjamin a experiência do sujeito com o mundo externo é a interpretação por esse novo sensorium. Assim, os signos, na qualidade mediadora, são criações culturais externas (há materialidade) que se tornam mentais (função simbólica) quando são internalizados pelo sujeito, tornando-se representações. Assim a cultura serve como alargadora das potencialidades humanas, o que nos permite dizer que a passagem da ontogênese para a sociogênese se dá quando a cultura toma a pauta biológica e a interpreta (OLIVEIRA, 1999).

A experiência é, portanto, o modo como estabelecemos relações a partir de um processo transmitido de geração em geração, um ato de conhecimento formativo do mundo, ou seja, está no cerne da formação humana. A narrativização da experiência é a decorrência e a consumação da busca de sentido para o tempo vivido através da organização do puro devir em um todo com princípio, meio e fim, no qual o encadeamento dos acontecimentos sugere por si mesmo uma inteligibilidade a ser interpretada e apropriada pelo ouvinte, leitor ou espectador.

Esse modo de sentir e perceber condiciona-se ao contexto vivenciado e, consequentemente, sofre influência direta dos agentes atuantes nesse espaço/ tempo determinado. Isso aparece fortemente em Benjamin quando o autor discutiu o impacto da reprodução em série das obras de arte, especialmente a partir do advento da fotografia e do cinema, bem como das novas espacialidades desencadeadas pelos processos de consumo do capitalismo (as galerias em sua

No original: "Más que interesarse por los grandes momentos de la historia, los grandes hombres, las batallas, cede el lugar a la vida cotidiana de la ciudad, y lo que él llama la historia secreta de la ciudad, la anécdota. Le preocupan los anúncios, los escaparates, los carteles, toda clase de objetos efémeros, cartas, diarios personales, cualquier tipo de fenómenos marginales. Y esto es lo que le permite conocer la verdadera vida cotidiana del siglo XIX. Benjamin se consideraba a sí mismo una espécie de colecionista de retazos y resíduos" (WECHSLER, 2015). 
época, os shopping centers do final do século XX e até mesmo o comércio on-line do século XXI) propondo então a necessidade de se compreender esse "novo sensorium" da sociedade em que vivia. Segundo ele, "no interior de grandes períodos históricos, a forma de percepção das coletividades humanas se transforma ao mesmo tempo em que seu modo de existência" (BENJAMIN, 1986, p. 169).

Martín-Barbero dialoga com Benjamin na compreensão das condições socioculturais e políticas de nosso tempo - e sua relação com o conceito de sensorium - já na edição inaugural do livro De los medios a las mediaciones. O autor retoma essa discussão em 2017, enfatizando não só noção de obra "aberta", bem como sua proposição de tempos e espaços. Martín-Barbero reitera que Benjamin pensou as mudanças que configuram a modernidade a partir do espaço da percepção, misturando para isso o que se passa nas ruas, nas fábricas, nas escuras salas de cinema e na literatura, sobretudo na marginal, na maldita. Essa influência benjamininana se torna tão importante na compreensão do contemporâneo que, na mesma conferência, Martín-Barbero apresenta uma nova versão de seu mapa das mediações ${ }^{5}$, em que aparece a mediação da sensorialidade em eixo diacrônico, portanto, direto e indissociável, com a mediação da tecnicidade.

Pensar a sensorialidade diz respeito à experiência, ou seja, não apenas vivenciar, mas ultrapassar essa ideia, reconstruindo-a na contemporaneidade a partir de outros tempos e espaços. Significa analisar as mudanças estruturais geradas pela modernidade e sua relação com a percepção ampliada dos sentidos com base em conceitos como a aura, choque, distração, desvios, experiência e vivência, sendo que estes se encontram entrelaçados pelas circunstâncias definidas por uma nova realidade sociocultural e principalmente tecnológica. Entender a vida como experiência é perceber a transformação do tempo vivido em um todo rico em significados e possível de ser transmitido pela capacidade de narrar, de contar histórias e de se relacionar com elas. 
Ela (a experiência) sempre fora comunicada pelos mais velhos aos mais jovens, com a autoridade da velhice, em provérbios; de forma prolixa, com a sua loquacidade, em histórias; às vezes como narrativas de países longínquos, diante da lareira, contadas a filhos e netos (BENJAMIN, 2012, p. 123).

Resumidamente, pode-se dizer que a experiência é a junção de percepção e memória, um modo de articular acontecimentos singulares separados pelo tempo. Benjamin, principalmente nos ensaios "O narrador, considerações sobre a obra de Nikolai Leskov", "A obra de arte na época de sua reprodutibilidade técnica" e "Sobre alguns temas em Baudelaire", entende percepção e memória menos como atributos naturais e mais como capacidades plasticamente moldadas pelas condições de vida dominantes em uma época. O que podemos aqui chamar de princípio da historicidade da experiência é o pano de fundo para as análises de objetos e de formas de recepção por parte de Benjamin. Por outro lado, ao mesmo tempo em que acompanha uma narrativa na perspectiva de um fim, quem segue uma história coloca-se em cada parte ou episódio em um tempo presente, experienciando a situação dos protagonistas, levados a cada instante a tomar decisões sem saber como a história termina. Segundo o argumento de Barros Oliveira:

O ponto de vista dos protagonistas é uma representação do ponto de vista da chamada vida real, na qual não é possível ter certeza do que exatamente se seguirá de uma decisão tomada, e na qual nosso futuro está em jogo. Esse tipo de experiência o leitor/espectador tem diariamente: não saber, mas conjecturar, sobre o significado, no futuro, do que faz agora, o que pode ser aproximado de uma espécie de pré-narrativa. Esta seria modulada pela pergunta "como será que vou contar, no futuro, isso que faço agora?" Esse tipo de conjectura é modulado culturalmente. São as inúmeras narrativas que já acompanhamos que nos fornecem modelos para estruturar a narrativa de nossas vidas, como o lembra Paul Ricoeur. Uma narrativa oferece, então, um tempo com contornos, um trecho de vida em miniatura, capaz de ser abarcado pelo olhar e pela memória, e que comparece como esquema quando procuramos instaurar alguma ordem na nossa existência (BARROS OLIVEIRA, 2015, p. 306-307).

Antonio Candido, nos seus estudos sobre a teoria da personagem, afirma que "o enredo existe através das personagens; as personagens vivem no enredo" 
(CANDIDO, 2007, p. 53). A estrutura do romance baseia-se num certo elo entre o ser real e o ser fictício, sendo que esse ganhará forma concreta por meio da personagem. Ainda sobre o ser real e o ser fictício, Candido (1976) discorre sobre suas afinidades e diferenças afirmando que tais elementos são importantes porque conseguem criar um sentido de verdade, ou seja, o leitor/espectador, no momento que se depara com a personagem, identifica-se com ela. Todavia, todo esse possível entendimento da personagem justifica-se em razão da coerência à qual ela é submetida. O teórico acrescenta que "a compreensão que nos vem do romance, sendo estabelecida de uma vez por todas, é muito mais precisa do a que nos vem da existência. Daí podermos dizer que a personagem é mais lógica, embora não mais simples, do que o ser vivo" (CANDIDO, 2007, p. 59). Sobre o processo de identificação com os personagens, nesse caso na literatura, mas que pode ser estendido à ficção seriada audiovisual, Rosenfeld (2007) destaca que:

[...] o leitor contempla e ao mesmo tempo vive as possibilidades humanas que a sua vida pessoal dificilmente Ihe permite viver e contemplar, visto o desenvolvimento individual caracterizar pela crescente redução de possibilidades. De resto, quem realmente vivesse esses momentos externos, não poderia contemplá-los por estar demasiado envolvido neles. E se os contemplasse à distância (no círculo dos conhecidos) ou através da conceituação abstrata de uma obra filosófica, não os viveria. É precisamente a ficção que que possibilita viver e contemplar tais possibilidades, graças ao modo de ser irreal de suas de suas camadas profundas, graças aos quase-juízos que fingem referir-se a realidades sem realmente se referirem a seres reais; e graças ao modo de parecer concreto e quase sensível deste mundo imaginário nas camadas exteriores (ROSENFELD, 2007, p. 46, grifos nossos).

A organização da narrativa com ênfase no personagem, típico do romance, e que se apresenta de forma potencializada nas séries, somada ao objetivo de apresentar seus mundos ficcionais como paráfrases da realidade, estabelecem um processo de sensibilidade aguda em relação à vida contemporânea. Nesse sentido, afirma Jost:

Se as séries americanas podem parecer tão próximas, apesar de sua estranheza, é por que elas se fundam em ideologias transnacionais, lugares comuns, como diriam os retóricos, que estão florescendo em muitos países: 
o complô [...]; a rejeição das elites, colocando em destaque as manipulações [...]. Mas o banho no qual estamos imersos explica também, e talvez, sobretudo, as reações dos personagens, dos quais funda a psicologia: ele motiva seus objetivos e, ao mesmo tempo, coloca o herói em uma situação que o espectador identifica como sua (JOST, 2012, p. 29-30).

A afirmação de que o sucesso das séries se dá graças à identificação que o espectador tem com o herói reforça o argumento de que interagir com a narrativa, nessa perspectiva, tem muito mais a ver com o desejo sensível do espectador de se colocar no lugar do personagem, modificando a realidade e obtendo sua revanche em relação a situações e instituições que o dominam. "O sucesso das séries explica-se menos pela sua capacidade de refletir de forma realista sobre o nosso mundo do que por suas condições de fornecer uma compensação simbólica" (JOST, 2012, p. 69).

Jean Pierre Esquenazi destaca que a recepção das séries e a cumplicidade dos públicos estão relacionadas a uma identificação sensível com os personagens. Esquenazi cita Ien Ang (1991), David Buckingham (1987) e Dominique Pasquier (1999) para reafirmar o poder das séries de conquistar receptores por meio de uma identificação emocional entre eles e os personagens. Ien Ang chamou esse fenômeno de "realismo emocional em Dallas" e afirmou que não era possível menosprezar esses conteúdos quando todos interpretavam suas próprias vidas através deles. Buckingham caracterizou a adesão às séries como implicação alegre, um distanciamento crítico, uma capacidade de se colocar no lugar dos personagens e discutir suas escolhas no próprio cotidiano. Pasquier (2010) demonstrou que os espectadores distinguem perfeitamente o real do ficcional e veem os comportamentos dos personagens como modelos que podem comentar e até seguir, de acordo com critérios aplicáveis à realidade.

Voltamos então à questão central do artigo: o consumo das séries seria mais uma tentativa de experiência estética relacionada ao convite para vivenciar no presente o lugar do personagem do que o de ser conduzido por uma narrativa na qual já se prevê os acontecimentos? Qual o papel do personagem nesse processo de fruição e experiencialidade, inseridas em um novo sensorium, e o quanto ele é preponderante na ficção seriada por streaming? 


\section{Reflexões estéticas na narrativa seriada}

Do ponto de vista mais tecnicista poderíamos afirmar, seguindo a lógica de autores como Nicholas Carr (2010) ou Marshall MacLuham, que sustentam a tese de que nosso cérebro é muito mais moldado pela experiência do que condicionante de suas estruturas, que o consumo excessivo da ficção seriada seria uma imposição do modo de vida digital e não de uma prática que se relaciona com a experiência do sujeito com uma narrativa e com seus personagens. Porém, o que apostamos aqui é que a "experiencialidade" gerada pelas séries está atrelada a um tipo específico de imersão temporal no espaço ficcional. Obviamente o aspecto tecnológico é condicionante, mas só ele não poderia determinar tal comportamento.

Parte-se então para um esforço argumentativo no sentido não só de superar a visão da tecnicidade, mas de fortalecer na narrativa a importância do personagem, o caráter episódico e o enfraquecimento do enredo como eixos analíticos fundamentais nesse tipo específico de fruição. Como se cada temporada tivesse um desenvolvimento próprio, o tempo passasse de forma um tanto quanto indefinida e os personagens fossem os elos de identificação do espectador, levando-o não somente a vivenciar as possibilidades, mas também a ter condições de narrá-las futuramente.

Martín-Barbero e outros pesquisadores culturalistas defendem a ideia de que o entendimento de um gênero/formato leva à compreensão de como os meios audiovisuais articulam-se com as matrizes culturais com as quais os sujeitos se constroem individual e socialmente. Para o autor, os gêneros são, entre outras coisas, modelos de construção e de compreensão do mundo "real" e do mundo ficcional, imbricados na composição ou no reforço de ideologias, socialidades e imaginário popular. Mas se pensarmos a partir de uma relação sensível com esses conteúdos, quais seriam os elementos centrais de alargamento da percepção e de fruição nas séries?

A base dessa discussão está na hipótese de "estar no lugar de alguém", vivenciar seu universo e se fixar em um tempo específico. Essa outra temporalidade já foi discutida por Benjamin, a partir de Aristóteles, e recebeu o nome de mimesis, algo 
presente desde sempre e até hoje nas autênticas brincadeiras infantis de faz-de-conta. A mimese, para o autor, designa um processo de aprendizagem específico do humano (em particular das crianças), em que a aquisição de conhecimentos é favorecida pelos aspectos prazerosos do processo. Poderíamos dizer que o impulso mimético está na raiz do lúdico e do artístico. Ele repousa sobre a faculdade de reconhecer semelhanças e de produzi-las na linguagem. A definição de mimesis também foi abordada por Käte Hamburger (1986) para discutir o conceito de ficção. Segundo ela, o significado de mimesis não contém apenas a ideia de imitação e deve-se considerar nessa palavra o significado de representação. Aristóteles tem ainda outra definição fundamental para a constituição do conceito de ficção: a verossimilhança, que seria um princípio que rege a criação (literária): "[...] a obra do poeta não consiste em contar o que aconteceu, mas sim coisas que podiam acontecer, possíveis no ponto de vista da verossimilhança ou da necessidade" (ARISTÓTELES, 1995, p. 28).

Nessa perspectiva, a relação do espectador com as séries não se funda apenas no princípio de imitação da realidade, mas principalmente sobre o princípio da representação de (uma) realidade, ou seja, da criação de um mundo ficcional que se assenta sobre as relações simbólicas construídas socialmente. Essa capacidade de representar ou imitar tende a se concretizar na relação do espectador com o personagem, ou melhor, na possibilidade de se colocar na temporalidade vivida por esse sujeito em uma determinada época. Uma sequência de acontecimentos que dizem quem é aquele personagem e "como" é ser ele naquele tempo específico. Esquenazi aponta que um dos principais motivos do sucesso das séries de TV (ou da ficção seriada audiovisual de maneira mais ampla) reside justamente na possibilidade de acompanhar a trajetória dos personagens: 
Ou seja, a lógica diferenciada da temporalidade das séries em relação a outras narrativas "permite aos espectadores a observação da intimidade das personagens" (ESQUENAZI, 2011), algo que poucas formas de ficção tornam possível e que ajuda a compreender o envolvimento dos receptores com essas narrativas e, portanto, se apresenta como um aspecto muito importante a ser levado em conta nos estudos de recepção e consumo dessas narrativas. Mais do que pensar o que do conteúdo dessas narrativas mobiliza o público, o desafio está em pensar em como a identificação com as personagens estabelece esses vínculos subjetivos e experienciais.

O enredo serviria mais como elemento para situar e descrever personagens do que eixo central da experiência. Por isso, o caráter episódico proporcionado pela obra aberta e impossibilitado nas formas mais fechadas de enredo, como o cinema de longa-metragem ou mesmo o romance em sua faceta mais tradicional, ganham espaço nas séries e com elas a noção de personificação se estabelece. Assim sendo, mesmo que não em sua maioria, as séries como narrativas muitas vezes são fracas de enredo, mas fortes em personagens. São eles que fixam a temporalidade do espectador na narrativa levando-o a acompanhá-las fielmente. De acordo com Rosenfeld (2007), o personagem vai ser definido nitidamente aos olhos do leitor, quando engendrado no tempo e na ação da narrativa, cabendoIhe revelar o caráter ficcional do texto:

Há numerosos romances que se iniciam com a descrição de um ambiente ou paisagem. Como tal poderia possivelmente constar de uma carta, um diário, uma obra histórica. É geralmente com o surgir de um ser humano que se declara o caráter fictício (ou não-fictício) do texto, por resultar daí a totalidade de uma situação concreta em que o acréscimo de qualquer detalhe pode revelar a elaboração imaginária (ROSENFELD, 2007, p. 23).

Diante de aspectos levantados por Rosenfeld na obra de Antônio Candido (2007) percebemos que o escritor, ao criar seus seres ficcionais, pode inspirarse em um modelo real, conhecido direta ou indiretamente e que vale como um pretexto básico, um estimulante para o trabalho de caracterização, o qual explora 
ao máximo as virtualidades da personagem através da fantasia. Outra técnica sugerida pelo autor é a construção das personagens por meio de um modelo real dominante, que se junta a outros modelos secundários, refeitos e constituídos pela imaginação. As personagens também podem ser elaboradas com fragmentos de diversos modelos vivos, tendo como produto final uma personalidade nova.

Com isso, a personagem é constituída a partir da representação de um ser humano, em que o autor projeta suas experiências mundanas, estabelecendo um elo entre o universo real e o ficcional e, por si só, um caráter de verossimilhança. Logo, é possível que os espectadores se identifiquem com determinada personagem e sua trajetória dentro da narrativa. Assim, as personagens obedecem a uma determinada concepção de humano, a um intuito simbólico ou a outros estímulos, corporificados pelo autor, baseados numa experiência de vida mais interior do que exterior.

Esse aspecto é muito característico da ficção seriada, já que a linguagem das séries tende a privilegiar os personagens de forma que não é possível perceber a ordem exata dos acontecimentos, mas no decorrer da narrativa o espectador traça seu caminho e pode ordená-los. É comum que um mesmo episódio possa ser narrado por pontos de vistas diferentes, ou seja, em cada momento uma determinada personagem mostra sua interpretação, e com isso, permite que o espectador interprete da maneira que melhor Ihe convém.

Com isso, as séries, assim como o romance moderno, envolvem em sua caracterização os sentimentos de suas personagens, sua vida interior, e principalmente os seus sentimentos contraditórios. Essa complexidade dos personagens e sua articulação com a recepção já foi discutida por Foster na sua categorização dos personagens no romance, em que o autor divide as personagens em flat characters (personagens planas) e round characters (personagens redondas ou esféricas). Sobre as personagens planas, Forster afirma:

As personagens planas eram chamadas temperamentos (humours) no século XVII, e são por vezes chamadas tipos, por vezes caricaturas. Na sua forma mais pura, são construídas em torno de uma única ideia ou qualidade; quando há mais de um fator neles, temos um começo de curva em direção à esfera (FORSTER apud CANDIDO, 1949, p. 66-67). 
As personagens redondas (ou esféricas), em oposição às planas, são seres fictícios de alta complexidade. São dotadas de uma identidade própria, apresentando características tão variadas e distintas que dificultam sua associação a uma ideia específica até quando pertencem ao mesmo tipo social, mas apresentam qualidades e valores predominantes ou características exageradas. As personagens redondas não são definidas com muita clareza por Forster, que utiliza a imprevisibilidade como critério para sua classificação: "A prova de uma personagem esférica é a sua capacidade de nos surpreender de maneira convincente. Se nunca surpreende, é plana. Se não convence, é plana com pretensão a esférica. Ela traz em si a imprevisibilidade da vida, traz a vida dentro das páginas de um livro" (FORSTER, 1949, p. 70).

Nas séries, o tipo esférico é extremamente explorado e obedece a uma lei própria, uma coerência interna. Dada à impossibilidade de descrever a totalidade de uma existência, os personagens são de certa forma convencializados tal qual a estrutura do romance, ou seja, são dados a eles traços que despertem vínculo com a vida real, uma organização estética que, ao funcionar, demanda que o espectador aceite inclusive o que é inverossímil, como é o caso das distopias. Isso causa no espectador a sensação de que a autenticidade externa, da narrativa e dos fatos, garante o sentimento de realidade. Tem-se com isso, como afirma Candido:

A ilusão de que a ficção é assegurada, de modo absoluto, pela verdade da existência, quando nada impede que sede exatamente o contrário. Se as coisas impossíveis podem ter mais efeito de veracidade que o material bruto da observação ou do testemunho, é porque o personagem é, basicamente, uma composição verbal, uma síntese de palavras sugerindo certo tipo de realidade (CANDIDO, 2011, p. 78).

Outra estratégia bastante comum nas séries é a experimentação dos tempos do personagem em diferentes momentos da sua trajetória, seja através de flasbacks, seja em situações paralelas dentro da narrativa. Acrescenta-se aqui uma terceira temporalidade: a percepção que o espectador tem do tempo psicológico do personagem, ou seja, daquilo que se passa em sua mente. Esta fusão de temporalidades, o tempo cronológico com o psicológico, acaba por 
potencializar um tipo de imersão do espectador que exige maior atenção e molda sua percepção. Assim, na sua potencialidade estética, as narrativas seriadas hibridizam noções de realidade na descrição detalhada dos personagens, como explorado pelos romancistas do século XVIII, com o convencimento a partir da aproximação com a realidade observada, uma mistura bem realizada que confere poder de convicção. Cada traço adquire sentido em função do outro, de modo que a verossimilhança depende da unificação do fragmentário pela organização e ressignificação do contexto percebido pelo espectador.

Todos os argumentos apresentados remetem à hipótese de que os personagens retomam força nas narrativas seriadas em um contexto digital, como nos grandes romances e folhetins. Isso é facilmente comprovado se analisarmos empiricamente alguns dos maiores sucessos de crítica e audiência no mercado das séries nos últimos anos. Terminamos colocando em discussão um último argumento apresentado por Barros Oliveira (2015) e que consideramos desafiador para pensar essas novas temporalidades. Segundo o autor, a ênfase nos personagens e a experiencialidade discutidas neste artigo são uma tentativa de burlar a despresencialização predominante em nosso atual meio tecnológico.

A busca por presença através de personagens pode ser vista como escapatória à transferência do espaço vital para a era da ubiquidade, a nossa época da abdicação da presença no aqui e agora em prol da disponibilidade absoluta para as redes de comunicação social? Ao visitar museus em qualquer lugar do mundo, por exemplo, chama a atenção o gesto corriqueiro dos visitantes de fotografar os quadros com o celular sem sequer parar para olhá-los, postergando para um remoto depois (e transferindo para um vago e indefinido quem) a experiência efetiva de vê-los uma vez que seja. Contra esse impulso, que está mais presente em nossa vida cotidiana do que gostaríamos de admitir, pode ser que o gosto por acompanhar personagens represente um inconsciente foco de resistência. Não que deste hábito nos pareça que vá surgir algum impulso revolucionário, mas ele sintomatiza uma carência por clareza e nitidez da imagem do outro e de nós mesmos como um outro, sem a fragmentação do mundo informativo, sem a dispersão extrema da atenção, ou seja, a personagem nos oferece algo que a consciência que podemos ter de nós mesmos e dos outros se mostra cada vez menos apta a realizar, nas atuais condições (BARROS OLIVEIRA, 2015, p. 217). 
Pode-se então concluir que a ficção seriada é hoje um exemplo de matriz cultural que vai ao encontro das condições da experiência contemporânea, na qual se pode ressignificar um novo modo de habitar o tempo, um modo antigo que se reorganiza a partir da tecnicidade e da consciência de um espectador imerso nesse novo sensorium.

\section{Considerações finais}

O artigo buscou tensionar a relação entre personagem e narrativa na ficção seriada usando o argumento de que as séries tendem a elaborar um jogo para o leitor/espectador que enfraquece a noção de fim, ao mesmo tempo em que fortalece a de personagem. Essa hipótese levou à conclusão de que, na narrativa das séries, a centralidade do enredo é enfraquecida em função do processo de negociação da audiência que, a partir da "experiencialidade", coloca-se no jogo de repetir a trajetória de alguém.

Experiencialidade, portanto, neste texto, não significou apenas vivenciar, mas ultrapassar essa ideia, analisando as mudanças estruturais geradas pela modernidade e sua relação com a percepção ampliada dos sentidos, reconstruindo-a a partir de uma temporalidade específica definida por uma nova realidade sociocultural e, principalmente, tecnológica. Entender a vida como experiência é perceber a transformação do tempo vivido em um todo rico em significado e transmitido pela capacidade de narrar histórias e de se relacionar com elas.

Partiu-se de uma discussão teórica sobre o crescimento do consumo de ficção seriada, focada na estrutura do texto narrativo e na relação entre esse tipo de consumo e a experiência estética, ou seja, um modo específico de fruição na qual o receptor está implicado. Essa fruição ocorre no momento em que o espectador acompanha uma narrativa, segue uma história e se coloca entre um início e um fim, um tipo de imersão de tentativa e erro, em que se vão tecendo hipóteses provisórias, até o momento em que a hipótese coincidirá com aquilo que ele lê, vê ou ouve.

É como se essa capacidade de conjecturar sobre os fatos fosse uma prénarrativa modulada culturalmente, ou seja, a narrativa das séries acaba por 
oferecer uma vida em miniatura capaz de ser abarcada pelo olhar e pela memória do espectador, instaurando uma ordem na sua existência. Nesse processo, a identificação com os personagens, típica do romance, é determinante nas séries, pois fortalece o ponto de vista da chamada vida real, apresentando o mundo ficcional como paráfrase da realidade, um processo de sensibilidade aguda em relação à vida contemporânea. Essa identificação pode operar também como revanche do espectador a situações e instituições às quais ele é subordinado, convertendo-se em uma compensação simbólica ou servindo de modelos aplicáveis à realidade e passíveis de serem seguidos.

Pretendeu-se superar a visão mais tecnicista, a qual sustenta que o consumo excessivo da ficção seriada seria uma imposição do modo de vida digital e não uma prática relacionada à experiência do sujeito com uma narrativa e seus personagens, apostando que é na "experiencialidade" que se constitui um tipo específico de imersão temporal que fixa o espectador e o faz se engajar em tais conteúdos. A complexidade dos personagens, a mimese enquanto imitação da vida, a verossimilhança e a hibridização entre os tempos cronológico e psicológico seriam princípios que regem a ficção seriada e que constituem essa temporalidade em que o receptor está inserido. Esses aspectos tornam imperceptível a ordem exata dos acontecimentos, mas no decorrer da narrativa o espectador traça seu caminho e pode ordená-los. Isso justifica o argumento de que as séries, mesmo que não em sua maioria, são narrativas muitas vezes fracas de enredo, mas fortes em personagens, pois são eles que fixam a temporalidade do espectador na narrativa e conquistam sua fidelidade.

Por fim, o texto procura, a partir de uma hipótese bastante desafiadora, refletir sobre o conceito de "experiencialidade" e sua relação com o mundo digital. Seria, então, a interação espectador/personagens e esse desejo de estar no lugar de alguém, uma tentativa de transferir para o espaço ficcional, a dificuldade de presencialização produzida pela ubiquidade? Será que, como afirma Bernardo Oliveira, experienciar as séries no lugar dos personagens não seria um ato de resistência, no sentido de encontrar clareza e nitidez da imagem do outro e de nós mesmos como um outro, sem a fragmentação do mundo informativo e sem a 
dispersão extrema da atenção? As respostas estão a um clique dos nossos dedos e esse é um campo vasto para se dedicar, seja na perspectiva teórica, seja na difícil transposição desse conceito para o campo empírico.

\section{Referências}

ARISTÓTELES. Poética. São Paulo: Nova Cultural, 2000 (Coleção Os pensadores).

BALOGH, A. M. O discurso ficcional na TV: sedução e sonho em doses homeopáticas. São Paulo: Edusp, 2002

BENJAMIN, W. A obra de arte na época de sua reprodutibilidade técnica. In: Benjamin, W. Obras escolhidas: magia e técnica, arte e política. São Paulo: Brasiliense, 1986. - Magia e técnica, arte e política: ensaio sobre literatura e história da cultura. In: Benjamin, W. Obras escolhidas. V. I. São Paulo: Brasiliense, 2012.

CÂNDIDO, A. A personagem do romance. In: CÂNDIDO, A. et al. A personagem de ficção. 12a. ed. São Paulo: Perspectiva, 2007.

CARR, N. The Shalow. What the internet is doing to our brains. New York: W. W. Norton \& Company, 2010.

ESQUENAZI, J.-P. As séries televisivas. Lisboa: Texto \& Grafia, 2011.

FEUER, J. Genre study and television. In: ALLEN, R. (ed.), Channels of discourse, reassembled: television and contemporary criticism. London: Routledge. 1992.

FISKE, J. Television culture. London: Routledge, 1987. 
FOSTER, E. M. Aspectos do romance. 2a. ed. Porto Alegre: Globo, 1974.

GARCÍA RIVERA, G. Diccionario digital de nuevas formas de lectura y escritura. Disponível em: http://dinle.usal.es/searchword.php?valor=Sensorium\% 20audiovisual\%20y\%20j\%C3\%B3venes.

HAMBURgeR, K. A lógica da criação literária. São Paulo: Perspectiva, 1986.

JOST, F. Do que as séries americanas são sintoma? Porto Alegre: Sulina, 2012.

MARTÍN BARBERO, J.; REY, G. Os exercícios do ver: hegemonia audiovisual e ficção televisiva. São Paulo: Senac, 2001.

MARTÍN-BARBERO, J. Dos meios às mediações: comunicação, cultura e hegemonia. 2a. ed. Rio de Janeiro: UFRJ, 1999.

MITTEL, J. Genre and television. Londres; Nova Iorque: Routledge, 2004.

MUNGIOLI, M. C. P. Gêneros televisuais e discurso: enunciação, ficcionalidade e interação na série Norma. Comunicação, mídia e consumo, v. 9, n. 24, maio 2012. Disponível em: http://revistacmc.espm.br/index.php/revistacmc/article/view/238.

OLIVEIRA, B. B. O personagem de ficção no mundo digital. Revista Viso, n. 17, jul.-dez., 2015.

OLIVEIRA, B. B. As narrativas seriadas e a experiência contemporânea. Revista O que nos faz pensar, n. 36, 2015.

OLIVEIRA, M. K. Vygotsky aprendizado e desenvolvimento: um processo sóciohistórico. São Paulo: Scipione, 1999. 
SILVA, M. V. B. Cultura das séries: forma, contexto e consumo de ficção seriada na contemporaneidade. Galáxia, n. 56, 2014.

\section{Filmografia}

The passages of Walter Benjamin. A documentary film. 55min. 2014. WECHSLER, Judith (escritora, diretora e produtora); O'CONOR, Erika Volchan (editora). Publicado na plataforma on-line de vídeos YouTube em 24 fev. 2014. Disponível em: https://www.youtube.com/watch?v=rsbzzMRdIBg. Acesso em: 3 set. 2015.

Submetido em: 2 set. 20 | aprovado em: 14 out. 20 